\title{
TuS PASOS EN LA NIEBLA
}

Dionisia GARCÍA

Pablo Núñez (Langreo, 1980) nos entrega un libro de poemas tras un periodo de silencio, puesto que su actividad literaria no ha cesado. Dicho espacio de tiempo es favorable para los poemas, como podremos comprobar en las páginas de Tus pasos en la nieblal , dividido en tres apartados: La belleza del mundo, Confidencias, Quizá unos pocos versos.

El autor dice de su vida en diferentes etapas y situaciones. Buscador de lo esencial, tiene «pactos» con la palabra, y así lo ha demostrado en su libro anterior, Lo que dejan los días, de 2014, que mereció el Premio Internacional de Poesía de la Universidad de Murcia.

Abre el libro el poema «Cape Cod morning». Los primeros versos dicen del hermanamiento con lo natural: «ella no sabe que al mirar los árboles / está observando en realidad su vida»; para seguir más adelante: «los árboles son hombres que no engañan». Es admirable la sensible armonía del poeta con el universo.

En el apartado Confidencias, y dado ese mundo de pensamiento que al autor acompaña, encontramos en el poema «Lecciones» estos versos: «solo quien te escucha y duda / tiene algo valioso que decirte».

El poema titulado «El texto del Nuevo Testamento», en la última parte del libro, hace referencia al tema mencionado en los dos últimos versos: «Señor, Hijo de Dios, creador de todo / incluso del amor a las palabras». Como advertimos, las palabras tienen protagonismo y enaltecen cualquier tema tratado en la poesía de Pablo Núñez, más que el tema en sí.

Getxo, año 2000. En el mismo apartado que antecede, el poeta nos lleva a un tiempo anterior para avivar cuanto fue vida, porque se trata de ese «pasar» que nos pertenece. Desde una tercera persona, Núñez crea una atmósfera familiar donde están los padres, los hermanos; la mención a la infancia, en Donosti; el recuerdo de Asturias, y la forma en que dijo: «Mi país es España».

La temporalidad, como podemos observar, recorre estas páginas para expresar las diferentes etapas vividas por el autor, comenzando por la juventud primera: «porque

${ }^{1}$ Pablo Núñez, Tus pasos en la niebla, Sevilla, Renacimiento, 2020. 
aún no sabíamos renunciar a ser libres». Patentes los recuerdos, el amor («lo que el amor hoy deja de nosotros»). Alegría hacia lo vivido y soñado, traído al presente, donde se fundamenta una nueva realidad, porque ya no somos los mismos. En el pasado, vivíamos sin más. Pablo Núñez sabe que escribir de lo inmediato no es el camino para la buena poesía. Si más lejanas las vivencias, mejor el resultado.

Recordemos «Salamanca», donde el autor afirma: «y ya todo es quietud porque eres dueño / del saber y la duda-son lo mismo-ante la incertidumbre del naufragio». El lector puede recoger el mensaje, el pensamiento del poeta, tras su paso por un lugar de culto a ese «saber».

No dejemos atrás la mención a los antiguos. Píndaro es uno de los elegidos. En el poema «Nostos» (regreso de un viaje), encontramos a Atenea y Poseidón. Los lugares adquieren importancia. En Verbier, una estación de esquí con sus «cumbres», un grupo de jóvenes disfruta el momento. Su fiesta contrasta con la contemplación, a lo lejos, de «las montañas de la muerte».

En páginas anteriores, el arte impone su presencia, como ocurre en la recreación de la Cathedral of St. John the Divine. También en la mención a Bach, en otro de los poemas.

Para finalizar, hemos de decir que Pablo Núñez es un referente a tener en cuenta por las nuevas generaciones, y sin duda por los lectores de la buena poesía. 